\title{
Start with a Seedling: Uncovering the Kindergarten Language and Literacy Curriculum One Leaf at a Time
}

\author{
LYNDSAY MOFFATT \\ University of Prince Edward Island
}

\begin{abstract}
While recent research has documented the myriad benefits of school gardening and food programs, many educators and administrators voice concerns that such programs may detract from their ability to cover mandated curriculum. Research suggests many curriculum areas can be addressed through such programs, however, little research has investigated how or whether such programs can support mandated language and literacy curriculum expectations. Through a content analysis of transcripts of audio data from a school gardening and food program that matched 24 kindergarten children with 17 adult and young adult volunteers, this study illustrates how such a program can support mandated language and literacy curriculum. Analysis suggests the children practiced important oral language skills, such as asking questions and expressing experiences while involved in the program. Findings suggest the need for more research into why educators and administrators often hesitate to engage in such programs and how such programs can support mandated curriculum expectations as well as language and literacy learning.
\end{abstract}

Keywords

kindergarten, gardening, food, mandated curriculum, language and literacy, environmental sustainability, food security

\section{Introduction}

In a recent talk about the future of education and multiliteracies, Luke and Robson (2015), assert that the future of our species depends on our ability to address current issues in education. While literacy researchers over the past few decades have done little to consider how literacy, education, and environmental degradation are related, a small group of scholars are turning their attention to how literacy education and research might contribute to more environmentally sound ways of interacting with local ecosystems (Moffatt, 2015a). The work of scholars such as Bang-Jensen (2012), Bowers (2011), Cutter-Mackenzie (2009), Pascoe and Wyatt-Smith, (2013) Schneider, Kozdras, Wolkenhauer, and Arias (2014), and Yagelski (2005), amongst others, can be seen as part of a nascent movement investigating how we might shift language and literacy education and research to consider literacies for environmental sustainability as New Literacies or as New Basics (Luke, 2001; Stibbe, 2009).

This paper can be seen as part of this small, but growing, wave in literacy education research, as it seeks to connect literacy learning with larger questions of social and environmental justice. This paper focuses primarily on how literacy educators interested in environmental sustainability might work within the current ideology of accountability where delivering provincially mandated curricula is often seen as the primary, or sole function of schools, teachers and administrators. While many of us recognize the need for much broader and more radical changes in education if we are to mitigate the effects of climate change and address 
social inequality, ideologies of education as mandated curriculum delivery are deeply entrenched and require a range of responses. One way to bring literacies for sustainability into everyday classrooms may be to hear mainstream educators' and administrators' needs to "cover the curriculum" and to explicate how projects that support literacies for sustainability also address curriculum expectations. This paper documents how one school gardening and food program supported provincially mandated language and literacy outcomes and works to remind us of the rich possibilities for language learning in projects that are often seen as extra-curricular.

\section{Literature Review}

Recent research suggests school gardening and food programs are a useful means for addressing curriculum outcomes, issues of social inequality, and environmental sustainability (Byrd, Haque, Tai, McLellan, \& Knight, 2007; Food Secure Canada [FSC], 2011; Mayer-Smith, Bartosh, \& Peterat, 2007; Tarasuk, Mitchell, \& Dachner,, 2013). Current research suggests gardening and food programs can provide an authentic context for children's and adolescents' learning about mathematics (Civil \& Khan, 2001; Hinnant, 1999; Taylor, 2012), nutrition (Gatto, Ventura, Cook, Gyllenhammer, \& Davis, 2012; Gibbs et al., 2013; Morris, Koumjian, Briggs, \& Zidenberg-Cherr, 2002), science (Hachey \& Butler, 2009a, 2009b; Shoults \& Shoults, 2012), and environmental sustainability (Malone, 2004; Mayer-Smith, Peterat, \& Bartosh, 2006; Miller, 2007; Tangen \& Fielding-Barnsley, 2007). Additional studies have suggested that gardening with children and adolescents can have positive social effects such as fostering a sense of social inclusion (Dyment \& Bell, 2008; Nimmo \& Hallett, 2008), creating spaces for social interaction for children with special needs (Hussein, 2010) and increasing students' feelings of engagement and overall academic success (Skinner, Chi, \& Learning Gardens Educational Assessment Group [LGEAG], 2012).

However, when asked why they do not engage with such programs administrators and educators around the world routinely cite fears of losing instructional time, and the need to address state mandated curriculum expectations (Evans, Whitehouse, \& Gooch, 2012; Pedretti \& Nazir, 2014; Stevenson, Carrier, \& Peterson, 2014). In this way, it appears that we need more studies that illustrate how such projects address state mandated curriculum expectations.

In addition, while many studies have documented how gardening and food programs can support children's and young people's math and science learning, few studies have examined how such programs could also support language and literacy learning, or provincially mandated language and literacy curriculum. While Bang-Jensen (2012), Cutter-Mackenzie (2009), Pascoe and Wyatt-Smith, (2013), and Schneider, Kozdras, Wolkenhauer, and Arias (2014), have begun to investigate how school gardening programs can support language and literacy learning, none of these scholars has specifically tied their investigations to examining how such programs may support provincially or state mandated language and literacy curriculum expectations. Similar gaps can be seen in research on food and cooking programs. While food and cooking programs have been shown to have a positive impact on students' confidence in food preparation, and in guiding healthy food choices, as argued by Walters and Stacey (2009), few, if any, scholars, have examined how such programs may also support children's language and literacy learning, or mandated curriculum.

Given the central focus on language and literacy learning in elementary schools, and the current climate of educational accountability, if a program or activity cannot be shown to support provincially/state mandated language and literacy curriculum, it is unlikely to have much traction with schools, or school boards. As there are a wide range of authentic opportunities to read, 
write, speak, listen, view, and represent, in planning and planting a garden, and in preparing and cooking food, there is good reason to believe that participating in school gardening and food programs may support children's language and literacy learning as well as state mandated curriculum. However, as noted, little research exists that documents whether this is the case. Thus, research is needed to investigate whether, and/or how, school gardening and food programs support provincial/state mandated language and literacy curriculum.

The need for this research becomes all the more vital, in the light of recent research on environmental sustainability, food security and food sovereignty(Akinyemi, von Fragstein, \& Agnew, 2009; Chankook \& Fortner, 2006; Evans et al., 2012; Hazzard, Moreno, Beall, \& Zidenberg-Cherr, 2012; Monaghan \& Curthoys, 2008; Wilson, 2012). While many people understand the concept of environmental sustainability, food security and food sovereignty have only recently become terms that are used in national news reports. Food security has been defined as existing "when all people at all times have access to sufficient, safe, nutritious food to maintain a healthy and active life" Food and Agriculture Organization of the United Nations [FAO], 2015). Food sovereignty has been defined as "the right of peoples to healthy and culturally appropriate food produced through ecologically sound and sustainable methods, and their right to define their own food and agriculture systems" (FSC, 2011).

Food security and food sovereignty have become topics of concern in many regions of the world, including the region where this study was conducted. This study was conducted in a small city in the mainly rural province of Prince Edward Island (PEI), Canada. While this is a food producing province, PEI has the second highest rate of food insecurity in Canada, next to the far northern territory of Nunavut, and the rate of food insecurity appears to be rising. As argued by Tarasuk, Mitchell and Daniel (2014) the rate of food insecurity in PEI in 2012, was the highest rate yet observed in the province. Research suggests there has been a dramatic increase in the numbers of people relying on food banks in PEI since 2008, and an increase in the percentage of children being fed by food banks. The number of people using food banks in PEI has increased by $18.7 \%$ since 2008 , and the percentage of these people who use food banks who are under 18 has risen from $35.4 \%$ to $38.0 \%$. Research into the cost of buying healthy food in PEI suggests there has been a dramatic increase in the price of healthy food in the past few years as well. As documented by Walton and Taylor (2013), in eight years, from 2005 to 2013, the price of a healthy food basket on PEI (including products such as cheese, meat, fruit and vegetables) rose by $37.9 \%$. It is anticipated that food prices will continue to rise over the next decade as the climate continues to change in dramatic and unpredictable ways.

Research into the possible impact of climate change suggests that the next generation will have some significant challenges ahead of it, including learning how to respond to extreme weather patterns, global food shortages and an increase in social divides between those who have access to nourishing food and clean water and those who do not(Dietz, 2007; Hanlon \& McCartney, 2008; VanDeveer, 2011). In this way, learning how to respond to erratic and extreme weather, learning how to grow and distribute food more equitably and with less ecological damage, as well as learning how to mitigate and adapt to dramatic social, economic, and environmental changes, will become some of the most important skills young people can acquire or develop.

Food Secure Canada (FSC, 2011) has suggested that student gardens and food literacy programs could be one aspect of a strategy for insuring that all children have access to healthy food. Similarly, the Cooper Institute and the National Farmers' Union (Copper Institute \& National Farmers Union [CI \& NFU], 2012) assert that increasing young people's food skills, 
including learning about cooking healthy meals, and food production, could be a way to build food sovereignty and food security. Both Food Secure Canada (FSC, 2011), and the Cooper Institute and the National Farmers' Union (CI \& NFU, 2012), have recommended working with schools to help support these kinds of initiatives.

However, while all of this research suggests school gardening and food programs may be important and useful initiatives, to date, there has been very little evidence that local school boards, Ministries, or Departments of Education in any region across Canada have embraced educating children or young people about gardening or food as part of their mandate. As noted above, the most frequent deterrent appears to be fears that such programs will interfere with educators' ability to "cover" the mandated curriculum. Likely, research that can help document how school gardening and food programs can support provincial and state mandated curriculum may pave the way for ministries and departments of education to support such initiatives, and may contribute to the well being of the next generation.

This paper is designed to contribute to discussions of whether, and to what extent, a school gardening and food program can support the delivery of mandated provincial language and literacy curriculum, or whether such programs detract from such curriculum. By focusing on a content analysis of conversations between kindergarten children and adult volunteers in a year long intergenerational gardening and food program, the central research questions for this study are: 1) Does a school gardening and food program support provincially mandated language and literacy curriculum? And 2) If so, how, and to what extent, does this program support this curriculum; or, If not, how, and to what extent, does it detract from this curriculum?

\section{Theoretical Framework}

This study is informed by anthropological and sociological theories of literacy (Barton \& Hamilton, 2000; Street, 2001), learning (Lave \& Wenger, 1991; Rogoff, 2003) and educational research (Levinson \& Holland, 1996; Woods \& Hammersley, 1977). Anthropological and sociological theories of literacy and learning developed over the past 40 years have asserted the need to recognize that what counts as literacy changes over time, and that diverse literacies are valued differently in different socio-cultural contexts. These theories suggest researchers need to pay attention to the ways that literacies are constructed, or produced through social interaction, and how various literacies may be produced differently in different contexts. This perspective also reminds us that what counts as literacy right now, will likely change over the next decade. Recognizing that social issues play a significant role in determining what kinds of literacies are valued, the challenges of mitigating climate change, there is good reason to believe literacies for environmental sustainability may be important literacies for the next generation (Stibbe, 2009).

As argued by Luke (2003), Moje and Lewis (2007) and many others, anthropological and sociological approaches to research have a great deal to offer the study of language and literacy learning. In particular, these approaches recommend examining literacy learning through extended engagements with teachers and learners 'in the field' over significant periods of time, rather than through brief contact with subjects during experimental data collection. Anthropologists and sociologists of education assert that analysis of data generated through longterm engagements can offer researchers and educators rich illustrations of how learning happens, why it might not happen and the cultural production of values. These illustrations, in turn, can lead to deeper understandings of how educators can support students in acquiring new skills and new knowledge.

From these perspectives qualitative research methods such as participant observations, 
the generation of field notes, the generation of audio/video recordings, photography, and the collection of documents created by participants in the field, are particularly appropriate tools for understanding how children are apprenticed into different literacy practices (Barton \& Hamilton, 2000; Cook-Gumperz, 1986, 2006; Heath, 1983; Lave \& Wenger, 1991; Street, 2001; Wenger, 1998).

In addition, recently, Moje and Lewis (2007) have asserted the efficacy of incorporating sustained discourse analyses as a means for substantiating researchers' claims about their data. These scholars suggest that critical socio-cultural researchers, in particular, need to pay greater attention to the kinds of discourses produced in educational contexts in order to better understand various social processes and to support their findings. As the research questions for this study focus on describing whether and/or how mandated curriculum is, or is not, supported, anthropological and sociological perspectives are particularly appropriate. This study follows Moje's and Lewis' (2007) recommendation that researchers use both ethnographic and discourse analytic methods to investigate their research questions.

\section{Data Generation}

\section{Method}

Data for this study was generated during an intergenerational school gardening and food program known as "Start with a Seedling." During this program three kindergarten classrooms and adult volunteers worked together in small groups approximately once a month for three to four hours. These children and adults referred to each other as their garden buddies. As garden buddies, they visited a community garden, cooked a meal, discussed local food, painted still life pictures of winter vegetables, shared songs about soil and bugs, created classroom worm composters, created seed orders after looking through seed catalogues, planted seeds to grow in classroom light gardens, met with local farmers and visited a petting farm. The program began in October and continued until late May. The schedule for the year ran as follows:

\begin{tabular}{|l|l|}
\hline Date & Theme \\
\hline Mid Sept & Volunteer Orientation meeting \\
\hline Early October & Meet the teachers \\
\hline Mid October & Meet the kids: Songs \& Stories of Gardening \& Food \\
\hline Late October & Signs of Fall \& Fall Planting at Community Garden \\
\hline Mid November & Making Classroom Worm Composters \\
\hline Early December & Winter Foods Celebration \& Songs \\
\hline Mid January & Problem Solving: Growing Food Locally \\
\hline Mid February & $\begin{array}{l}\text { Still Life Painting of Winter Vegetables \& } \\
\text { Seed Catalogue Orders }\end{array}$ \\
\hline Late March & Local Farmers Visit \& Planting Light Gardens \\
\hline Mid April & Birds and Bugs in Books \& Sculptures \\
\hline Early May & Sketching Signs of Spring \& Spring Art \\
\hline Late May & Petting Farm Field Trip \\
\hline
\end{tabular}

Figure 1. Year Schedule

Data generation for this study included writing field notes, scanning children's and adults' work from "garden notebooks", taking some photographs, as well as recording audio and 
video while the garden buddies interacted. Field notes were written after visits with the volunteers and after meetings with the teachers to plan the garden buddies' visits. Photographs and video were taken throughout the program. However, this method of data generation was mostly limited to the one classroom where there was $100 \%$ parental consent for participation. In other classrooms, data generation was limited to some audio recordings and participant observations. In total, well over 200 hours of audio data were generated from approximately 11 small groups of children and adults.

\section{Participants}

The research participants in this study included 24 kindergarten children (aged 4-5 years), in three different classrooms in one inner city elementary school in Prince Edward Island, Canada. Convenience sampling was used to select these participants. The 24 child participants were drawn from a possible group of 46 children who attended kindergarten at this school. All 46 children were involved in the intergenerational gardening and food program, and all were given parental consent forms to take home. However, only 25 of these students returned their consent forms. When asked if they wanted to participate in the study, one of the children declined, and was thus removed from the list of research participants. These children came from a range of socio-economic, cultural and linguistic backgrounds. Some of the children were from dual income, middle class families, while other children were from single parent households. Some of the children came from longtime white settler families and others were first generation Canadians of colour. Some of the children in the study were monolingual English speakers while some spoke languages other than English and were English language learners. The inner city school chosen for this study was also chosen through convenience sampling as I knew the educators in these classrooms and the school was within walking distance from my home.

Adult and young adult volunteers in the program were also participants in the study. The adult and young adult participants came to the program via posters looking for volunteers and research participants. All of the adult and young adult participants were invited to an information meeting in September to learn about the program and the research study. They were then given the opportunity to participate in either the program, or the program and the research. All of the adult and young adult volunteers agreed to participate in the research. While there were 35 volunteers (aged 15-70), 17 of these were paired as "garden buddies" with the 24 children who had provided consent to participate. In this way, data generation focused on the 24 children and their 17 adult or young adult buddies. The adult and young adult participants included a young woman of 15 who had recently started being schooled at home, retired teachers, a retired social worker, a few retired nurses and a retired children's librarian. The young adult volunteers also included university students, recent university graduates and local young entrepreneurs. The majority of the adult and young adult volunteers were monolingual English speakers. However, there were also a few volunteers who spoke languages other than English.

\section{Analysis}

Analysis of the data is ongoing. This paper focuses specifically on a content analysis of three audio recordings captured during: 1) a field trip to a community garden where the adults and children harvested carrots and planted garlic, 2) a cooking day where participants created a well rounded meal from local foods, and 3) a problem solving activity in which the participants discussed how we might reduce pollution through consuming food that is grown locally. Audio data was chosen for analysis as it can provide powerful illustrations of what happened during the 
program and how oral language expectations were addressed throughout the garden buddies' visits.

Analysis of the audio data began with listening to and roughly transcribing seven hours of the audiotapes of the garden buddies' visits. The first tapes chosen for transcription were selected based on the quality of the recordings. Given the noisiness of the classroom during the garden buddies' visits, the audio tapes of these visits were extremely challenging to transcribe. A research assistant was engaged to transcribe interactions between three small groups of children and adults during three of these visits. These visits were transcribed verbatim and in their entirety using the transcription software Transana that requires the transcriber to listen to the audio and type what s/he hears.

The visits chosen for transcription occurred in late October, early December and midJanuary. The three main events in these visits were a trip to a community garden in October, a classroom cooking experience in December, and a problem solving experience in January. In the next phase of analysis, sections of each of these three visits were chosen for more detailed transcription. These finer transcriptions focused on the central activities of the visit, such as when the garden buddies were engaged in planting garlic or discussing a problem, rather than waiting for bus fare to be handed out. Times such as snack time, lining up, or when we were waiting for everyone to get their jackets on were left only roughly transcribed. While interesting conversations often took place in these "in between times", for this paper I have chosen to focus on the moments when the garden buddies were engaged in activities that were fairly unique to the program. For example, the teachers reported that unless they had the volunteers, they would not have ventured to the community garden, would not have cooked with the children and would not have engaged in the problem solving activity. These specific moments accounted for 240 minutes, or 4 hours of the 7 hours of audiotape initially chosen for rough transcription.

After transcribing these meetings, the expectations of the provincial mandated language and literacy curriculum were reviewed and these expectations were translated into codes that were used to code the transcripts. For example, Expectation 1.1 in the Oral Language section of the Kindergarten Integrated Curriculum Document states that by the end of kindergarten children will express feelings and opinions and describe personal experiences and interests. Given that opportunities to practice an expectation generally support children's chances of meeting that expectation, this expectation was broken down into four codes: $1.1(\mathrm{EF})=$ Express Feelings; 1.1(EO) = Express Opinion; $1.1(\mathrm{EE})=$ Express Experience; $1.1(\mathrm{EI})=$ Express Interest and every time a child performed one of these actions through his/her words it would be coded accordingly.

\section{Kindergarten Integrated Curriculum Document Expectation}

\section{Oral Language}

1.1 by the end of kindergarten children will express feelings and opinions and describe personal experiences and interests

\section{Codes from this Expectation}

$1.1(\mathrm{EF})=$ Express Feelings

$1.1(\mathrm{EO})=$ Express Opinion

$1.1(\mathrm{EE})=$ Express Experience

$1.1(\mathrm{EI})=$ Express Interest 
Figure 2. Kindergarten Integrated Curriculum Document Expectation

Other expectations that became codes included: 1.3 begin to ask and respond to questions, seeking help or information; 1.4 follow and give directions in different contexts; 1.5 participate in conversation and in small-and whole-group discussion; and 1.7 engage in simple oral presentations and respond to oral presentations. It bears noting that a few of the expectations in the curriculum document did not become codes as they could not be easily assessed in a content analysis of the audio data. For example, expectation 1.2 in the oral language section is: listen to the ideas and opinions of others. While at times we can infer that a child seems to be listening, or not listening, to the ideas or opinions of others, based on the way he or she responds verbally, it is far more difficult to code audio data for listening than for expressing. In this way, this analysis focuses particularly on children's expressive language rather than on their receptive language. A return to this data using an interactional analysis may help to isolate more evidence of children's listening. Similarly, the Oral Language expectation 1.6 begin to use gestures and tone to convey meaning was not used as part of the coding scheme as the audio data could not capture gestures, and noting changes in tone is a significantly more time consuming analysis than a simple content analysis. Future analyses may focus on this expectation.

\section{Other Oral Language Expectations that Became Codes}

1.3 begin to ask and respond to questions, seeking help or information

1.4 follow and give directions in different contexts;

1.5 participate in conversation and in small-and whole-group discussion

1.7 engage in simple oral presentations and respond to oral presentations

Figure 3. Other Oral Language Expectations that Became Codes

In order for the reader to get a sense of the coding of the data, an exchange between Karrie, Julian, (children) and Lara (an adult) while they were planting garlic at the community garden and how it was coded follows:

Excerpt 1: Planting Garlic (Coded)

\begin{tabular}{|l|l|}
\hline $\begin{array}{l}\text { Karrie: What is this kind of garlic? I } \\
\text { don't... }\end{array}$ & 1.3 AQ Ask Question \\
\hline $\begin{array}{l}\text { Lara: Oh you can buy it at the store and ther } \\
\text { chop it up very fine and you cook it and you } \\
\text { it... have you ever had garlic bread before? }\end{array}$ & \\
\hline Julian: Yeah, I eat it a lot - & $\begin{array}{l}1.3 \text { RQ Respond to Question; } \\
1.1 \text { EE Express Experience }\end{array}$ \\
\hline
\end{tabular}

Figure 4. Excerpt 1: Planting Garlic (Coded)

After creating the codes, the transcripts were then read carefully and every instance where a child expressed a feeling, opinion, experience, or interest was coded. Similarly, every time a child asked, or responded to a question, gave directions, engaged in an oral presentation, 
or responded to an oral presentation, these contributions were also coded. The codes 1.5 (SGC) Participates in a small group conversation and 1.5 (WGC) Participates in a whole group conversation were used sparingly, as the children were fairly consistently engaged in either small group or whole group conversations. In this way, the code was used once at the beginning of a small group or whole group conversation, rather than at every conversational turn.

In order to insure reliability in the coding, a graduate student research assistant and the primary investigator coded the transcripts independently and then compared their results. Any discrepancies were then discussed until we had a clear sense of how we were using the code. The codes were then tallied in order to get an idea of how often the children were practicing these skills while engaged in the program. Before beginning analysis, it was determined that if the design of the program created opportunities for the children to practice curriculum expectations daily, or in multiple ways, we would see this as evidence that the program can and does support the mandated language and literacy curriculum. If the program rarely provided opportunities for the children to practice or enact these expectations, or if it only provided opportunities for the children to practice some of the expectations, this finding would be taken as evidence that the program may support the mandated language and literacy curriculum. Finally, if the program did not provide any opportunities for the children to practice the end of year mandated curriculum expectations, this finding would suggest the program did not support the provincial language and literacy curriculum and that it might, in fact, detract from it.

\section{Findings}

In reviewing the data, there was strong evidence that this program supported significant pieces of the mandated kindergarten language and literacy curriculum by providing copious opportunities for the children to talk with mature language users. While some of the participating educators, and some of the administrators at the school board were concerned about how the program might limit instructional time, or prevent the teachers from covering important curriculum expectations, careful analysis of the transcripts of the conversations between the children and the volunteers suggests the program provided multiple opportunities for the children to demonstrate and practice important language and literacy skills. In particular, analysis of the data provides evidence that when they were engaged in the program, the children were given repeated opportunities to practice skills such as expressing opinions, describing experiences, and asking and responding to questions. The children could be heard to do these things many times a minute throughout the program. In looking at the three transcripts we found that the children used these skills on average once every 25 seconds during interactions with their garden buddies. In the 240 minutes of interaction transcribed, the children used their expressive language skills 580 times. In particular, they asked a great many questions and expressed many feelings, opinions and experiences. The chart below represents the children's utterances during the three transcribed interactions. 


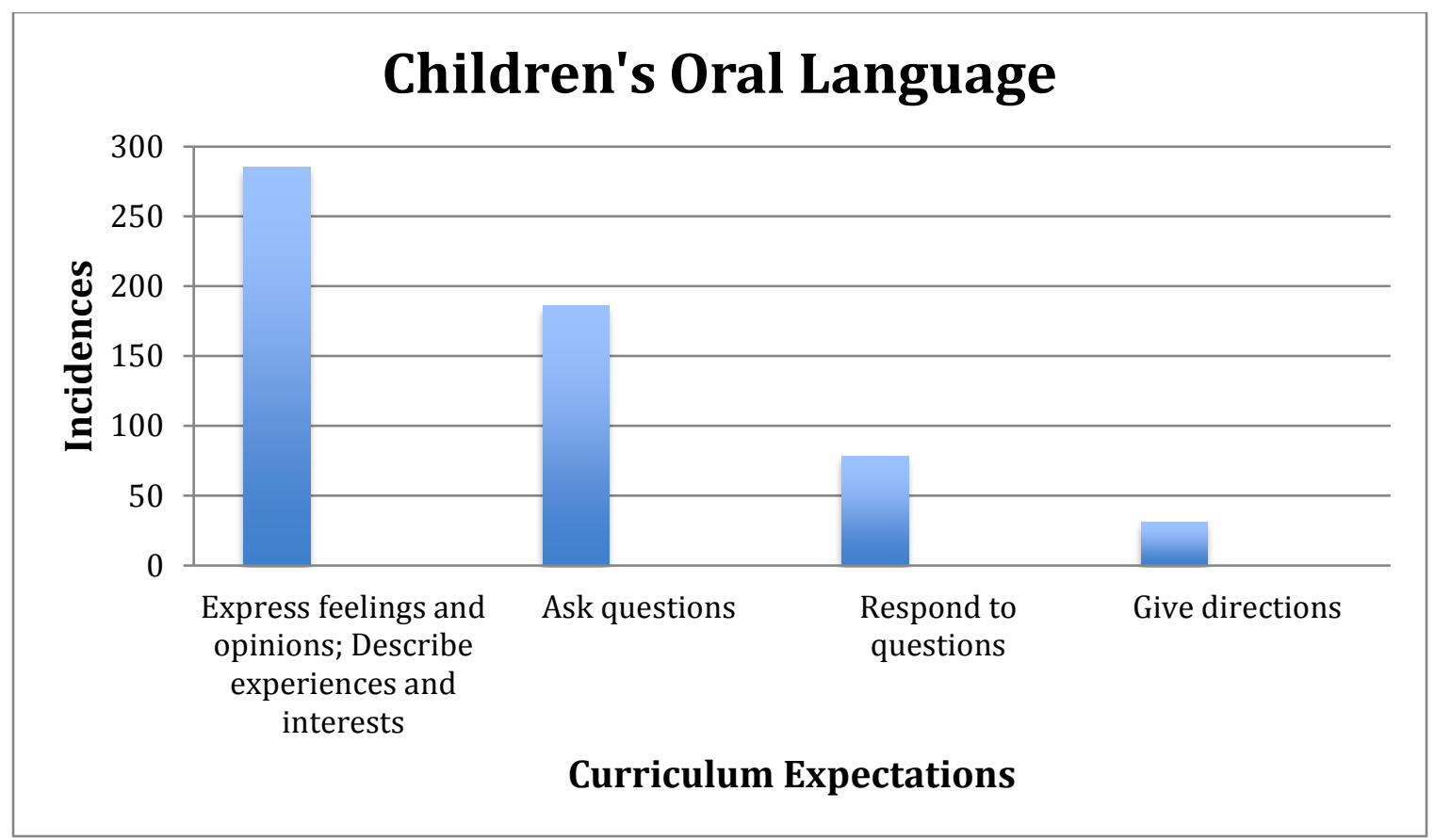

Figure 5. Children's Expressive Oral Language During Three Interactions (240 Minutes)

In order to get a sense of what these adult-child interactions sounded like below is a typical exchange from the first transcript, a conversation between two adult volunteers Tom and Lara, and two children Julian and Karrie, on the field trip to a community garden. The children have harvested carrots and are now washing them at the outdoor wash station:

Lara (Adult): I'm gonna wash your carrot for you

Karrie (Child): Can I help you wash it?

Lara (Adult): Yeah, oh my goodness

Karrie (Child): Do you do this with this carrot?

Lara (Adult): You can if you want to, you can really scrub it good, these are absolutely delicious

Karrie (Child): They are a snack

Lara (Adult): Pardon?

Karrie (Child): They are a good snack

Julian (Child): What is she doing? What are we going to do?

Lara (Adult): Okay let's make room for everybody else... Hi guys!

Karrie (Child): We are cleaning carrots now

Similarly, a conversation between two adult volunteers, Jane and Aiden, and three children, Lucy, Shep, and Ricky, while cooking potato latkes, sounded like this:

Aiden (Adult): Alright, I am going to put that in Shep (Child): Can I put some more pepper in? Aiden (Adult): Yes, you can put more pepper in Lucy (Child): We have to take turns with the oil 
When two adult volunteers Kim and Aiden, engaged with two children, Rachel and Shep, during a problem solving activity the following conversation ensued:

Aiden (Adult): See there are lots of things you can grow here and Shep's talking about things we can't grow here and we are never going to be able to grow everything, but maybe, but maybe here is an idea, we can grow a few things closer to home and then they don't have to come from so far away, so like in your backyard you could grow some carrots.

Rachel (Child): Great idea!

Aiden (Adult): That is an idea, you don't have to grow coconuts and mangos and coffee but you can grow some things.

Shep (Child): What else do you grow?

Rachel (Child): But my dad drinks, lots of coffee in the morning.

Aiden (Adult): But you don't have to worry about fixing everything all at once, one thing you can do to make it a little better.

Shep (Child): Aiden, what else do you grow?

\section{Discussion}

In examining these data, we can say with some assurance, that this school gardening and food program supported many of the mandated provincial language and literacy curriculum expectations. In particular, the children were given frequent opportunities to use their expressive oral language skills such as expressing opinions, asking and responding to questions. It bears noting that there are other aspects to the mandated language and literacy curriculum that have not been investigated here. In other words, expressive oral language is not the only skill children need to practice to be seen as "meeting expectations" by the end of their first year of school. By the end of kindergarten, children in Atlantic Canada are also expected to understand that print/illustration/symbols carry a message, to write simple messages themselves, and to begin to demonstrate an awareness of audience and purpose. Kindergarten graduates are also expected to regard reading and/or viewing as sources of interest, enjoyment, and information, to understand basic concepts of print including directionality, word, space, letter, and sound, to recognize and produce rhyming words in oral language" and to "identify how many words are in a spoken sentence. The analysis presented here cannot provide insight into how, or whether, participating in this gardening and food program provided support for these aspects of the mandated curriculum.

However, given that oral language experiences have long been identified as important for the development of alphabetic print literacy (Edmiaston, 1984; Huttenlocher, 1998; National Institute of Child Health and Human Development [NICHD], 2005; Shanahan, 2006), this program may well be contributing to both the children's oral language learning and to their development of alphabetic print literacy. Future researchers may want to investigate how, or whether children engaged in such programs show an advantage in developing print literacy. In addition, although this study does not offer a comparison between the children's regular classroom experiences and their experiences during the program, it is extremely likely that the children were given more opportunities to interact with mature language users during the program than during their regular classroom day. The usual ratio of adult to child conversation partners in a kindergarten classroom is approximately 1 adult to 15-17 children, having the volunteers present provided a ratio of approximately 1 adult to 1 or 2 children. Future research 
may want to compare the frequency and kind of interactions observed during this kind of program with those the children encounter in a regular school day. Similarly, future researchers may want to examine whether school gardening and food programs offer any other advantages when compared with other intergenerational programs focused on other topics.

While, children learn from each other, and talk to each other when they are given time to interact, and thus do not need adult interlocutors to practice their expressive language skills, there are important differences between practicing these skills with a peer, and practicing them with a more competent language user. From infancy to adulthood, having opportunities to interact with more competent language users is generally understood to be essential for language and literacy learning.

While the analysis here focuses specifically on the children's expressive language skills and does not provide much sense of what the adults in the conversation are doing, in reading the transcripts, the adults could be heard introducing advanced vocabulary and providing important feedback to their young interlocutors. For example, in the excerpt above, Lara, the adult washing carrots with Karrie, tells Karrie that the carrots are "absolutely delicious" using vocabulary that may well be new to Karrie as a young language learner. In addition, when she doesn't hear Karrie's statement she says "Pardon?" modeling what mature language users often do when they can't hear or want to initiate a repair. Similarly, in discussing how we might reduce the pollution that comes from transporting food onto the Island, Aiden, an adult participant, introduces the idea that some foods can be grown locally and others can't, a concept that appears to have been new to the children. In this way, we can recognize that the frequency of the children's contributions are only a thin sketch of what is happening in these conversations.

For many readers the findings of this study may seem anti-climatic, as most readers of academic research with teaching experience may already see "curriculum coverage" as a given when we engage young children in interesting activities. However, it bears noting that this project, like many others around the world, faced considerable resistance from educators and administrators at the school board. In particular, the principal's initial reaction to the project was to say pointedly "it has to address the curriculum", before hearing anything about the design of the program. Similarly, one of the teachers voiced concerns about holding the garden buddies meetings in the morning as this was the designated "literacy block". In addition, the school board ethics review panel initially delayed approval for this project and questioned the need to take the children outside. The panel suggested the program could be completed without leaving the classroom and constructed "the loss of instructional time" incurred by a trip to the local community garden as potentially an ethical issue.

These experiences, the documented resistance to gardening and food programs around the world, and the evidence presented here suggest future researchers may want to investigate why educators and administrators see such projects as "extra curricular" or how ideologies of literacy learning, kindergarten curriculum, and schooling may block initiatives in environment/garden/food education. As I have demonstrated elsewhere (Moffatt 2015a, 2015b) current ideologies of literacy learning, curriculum and schooling may well be affecting educators' ability to create meaningful engagement with environmental education. If this is the case, then Luke and Robson (2015) are right, the survival of the species may well be tied to our understandings of literacy and education. More research is needed to see how we might unearth such ideologies in diverse contexts and how we might learn to address them. As argued by Bowers (2011) and Yagelski (2005), educators responsible for language arts, including early literacy, may have an important role to play in this struggle. 


\section{Conclusion}

While many educators and administrators around the world are often reluctant to engage in school gardening and food programs for fear that such projects may detract from mandated provincial or state curriculum, evidence from this project suggests that the gardening and food program under study provided multiple opportunities for children's language and literacy learning. This study hopes to contribute to current research in several ways. First, this study provides a unique contribution to current research by documenting how, and to what extent, mandated language and literacy curriculum expectations can be addressed while children are engaged in a school gardening and food program. Given current challenges to implementing such programs and their potential benefits, this finding is important as it may help insure that school gardening and food programs are implemented and/or maintained.

This study also hopes to inform theories of how literacy learning is constructed in local contexts, and how educators can support young learners in acquiring new language and literacy skills. In slowing down to listen to children and volunteers in conversation, and to teachers' and administrators' concerns, this study may give educators and researchers a better idea of ideologies of literacy learning and how language and literacy expectations can be addressed in engaging ways. In other words, this study may provide an example of an innovative way of covering, or uncovering, mandated language and literacy curriculum that inspires other educators' classroom practice. However, it is also anticipated that the findings of this study may remind us to examine our assumptions about language and literacy learning and curriculum. Finally, this study may be useful for non-governmental organizations interested in addressing issues of food security, nutrition, or environmental sustainability in meaningful ways, and yet have little relationship with the school system. Recent discussions have stressed the need to find ways to provide food for people that does not diminish their dignity (FSC, 2011). Resourcing young people so that they can grow their own food, and transferring local food knowledge from one generation to the next, are some of the ways that this can be accomplished. This study is the first of a series of studies of how mandated language and literacy curriculum at different grade levels can be addressed through school gardening and food programs.

\section{References}

Akinyemi, O., von Fragstein, P., \& Agnew, D. (2009). The state of school gardening programs in sustainable development in Nigeria: Obstacles and opportunities. International Journal of Learning, 15(10), 231-245.

Bang-Jensen, V. (2012). Reading a garden. Educational Leadership, 69(9).

Barton, D., \& Hamilton, M. (2000). Literacy practices. In D. Barton \& M. Hamilton (Eds.), Situated literacies: Reading and writing in context (pp. 7-15). London: Routledge.

Bowers, C. (2011). Implications of the ecological crisis for the reform of teacher Education. Encounter, 24(2), 40-54.

Byrd, R., Haque, M., Tai, L., McLellan, G., \& Knight, E. (2007). Designing a children's water garden as an outdoor learning lab for environmental education. Applied Environmental Education and Communication, 6(1), 39-47.

Chankook, K., \& Fortner, R. (2006). Issue-specific barriers to addressing environmental issues in the classroom: An exploratory study. Journal of Environmental Education, 37(3), 15-22.

Cooper Insititute \& National Farmers Union. (2012). Food soverignity. Retrieved from http://www.cooperinstitute.ca/sitefiles/File/Food-Sovereignty-Brochure.pdf 
Civil, M., \& Khan, L. (2001). Mathematics instruction developed from a garden theme. Teaching Children Mathematics, 7(7), 400.

Cook-Gumperz, J. (1986). The social construction of literacy. New York: Cambridge.

Cook-Gumperz, J. (2006). The social construction of literacy. In J. Cook-Gumperz (Ed.), The social construction of literacy (pp. 1-18). New York: Cambridge University Press.

Cutter-Mackenzie, A. (2009). Multicultural school gardens: Creating engaging garden spaces in learning about language, culture, and environment. Canadian Journal of Environmental Education, 14(1), 122-135.

Dietz, S. (2007). The impacts of climate change: Perspectives from the Stern Review. Brown Journal of World Affairs, 13(2), 173-185.

Dyment, J., \& Bell, A. (2008). "Our garden is colour blind, inclusive and warm": Reflections on green school grounds and social inclusion. International Journal of Inclusive Education, 12(2), 169-183.

Edmiaston, R. (1984). Oral language and reading: How are they related for third graders? Remedial and Special Education, 5(4), 33-37.

Evans, N., Whitehouse, H., \& Gooch, M. (2012). Barriers, successes and enabling practices of education for sustainability in far North Queensland schools: A case study. Journal of Environmental Education, 43, 121-138. doi: 10.1080/00958964.2011.621995

Food Secure Canada. (2011). Resetting the table: A People's food policy for Canada: Food Secure Canada.

Gatto, N, Ventura, E, Cook, L, Gyllenhammer, L., \& Davis, J. (2012). LA Sprouts: A gardenbased nutrition intervention pilot program influences motivation and preferences for fruits and vegetables in Latino youth. Journal of the Academy of Nutrition \& Dietetics, 112(6), 913-920. doi: 10.1016/j.jand.2012.01.014

Gibbs, L., Staiger, P., Johnson, B., Block, K., Macfarlane, S., Gold, L., Kulas, J., Townsend, M., Long, C., Ukoumunne, O. (2013). Expanding children's food experiences: The impact of a school-based kitchen garden program. Journal of Nutrition Education and Behavior, 45(2), 137-146.

Hachey, A., \& Butler, D. (2009a). Science education through gardening and nature-based play. Young Children, 64(6), 42-48.

Hachey, A., \& Butler, D. (2009b). Seeds in the window, Soil in the sensory table: Science education through gardening and nature-based play. Young Children, 64(6), 42-48.

Hanlon, P., \& McCartney, G. (2008). Peak oil: Will it be public health's greatest challenge. Public Health, 122(2), 647-652.

Hazzard, E., Moreno, E., Beall, D., \& Zidenberg-Cherr, S. (2012). Factors contributing to a school's decision to apply for the California instructional school garden program. Journal of Nutrition Education and Behavior, 44(4), 379-383.

Heath, S. (1983). Ways with words: Language life and work in communities and classrooms. New York, NY: Cambridge University Press.

Hinnant, H. (1999). Growing gardens and mathematicians: More books and math for young children. Young Children, 54(2), 23-26.

Hussein, H. (2010). Using the Sensory Garden as a Tool to Enhance the Educational Development and Social Interaction of Children with Special Needs. Support for Learning, 25(1), 25-31.

Huttenlocher, J. (1998). Language input and language growth. Preventatitve Medicine, 27(2), 195-99. 
Lave, J., \& Wenger, E. (1991). Situated learning: Legitimate peripheral participation. Cambridge, UK: Cambridge University Press.

Levinson, B., \& Holland, D. (1996). The cultural production of the educated person: An introduction. In B. Levinson, D. Foley \& D. Holland (Eds.), The cultural production of the educated person: Critical ethnographies of schooling and local practice (pp. 1-51). Albany, NY: State University of New York Press.

Luke, A. (2001). The Queensland "new basics" : An interview with Allan Luke. English in Australia (129-130), 132-140.

Luke, A. (2003). Literacy and the other: A sociological approach to literacy research and policy in multilingual societies. Reading Research Quarterly, 38(1), 132-141.

Luke, A., \& Robson, C. (2015). Education after Snowden: Teaching and learning about the new information order [Video].

Malone, K. (2004). "Holding environments": Creating spaces to support children's environmental learning in the 21st century. Australian Journal of Environmental Education, 20(2), 5366.

Mayer-Smith, J., Bartosh, O., \& Peterat, L. (2007). Teaming children and elders to grow food and environmental consciousness. Applied Environmental Education and Communication, 6(1), 77-85.

Mayer-Smith, J., Peterat, L., \& Bartosh, O. (2006). Growing together to understand sustainability - an intergenerational farming project. In W. Filho (Ed.), Innovation, Education and Communication for sustainable development (pp. 361-378). Frankfurt am Main, Germany: Peter Lang.

Miller, D. (2007). The seeds of learning: Young children develop important skills through their gardening activities at a midwestern early education program. Applied Environmental Education and Communication, 6(1), 49-66.

Moffatt, L. (2015a). Surveying the field: Literacy education research for environmental sustainability. Literacy and Social Responsibility, 8(1), 3-14.

Moffatt, L. (2015b). Sowing Seeds: The cultural production of curriculum, environmental education and schooling in a teacher inquiry group. Paper presented at the American Anthropological Association Denver, Co.

Moje, E., \& Lewis, C. (2007). Examining opportunities to learn literacy: The role of sociocultural literacy research. In C. Lewis, P. Enciso \& E. Moje (Eds.), Reframing sociocultural research on literacy: Identity, agency and power (pp. 15-48). London, UK: Routledge.

Monaghan, K., \& Curthoys, L. (2008). Addressing barriers to ecological literacy. Pathways: The Ontario Journal of Outdoor Education, 20(3), 12-16.

Morris, J., Koumjian, K., Briggs, M., \& Zidenberg-Cherr, S. (2002). Nutrition to grow on: A garden-enhanced nutrition education curriculum for upper-elementary schoolchildren. Journal of Nutrition Education \& Behavior, 34(3), 175.

National Institute of Child Health and Human Development. (2005). Pathways to reading: The role of oral language in the transition to reading. Developmental Psychology, 41(2), 482442.

Nimmo, J., \& Hallett, B. (2008). Childhood in the Garden: A Place to Encounter Natural and Social Diversity. Young Children, 63(1), 32-38.

Pascoe, J., \& Wyatt-Smith, C. (2013). Curriculum literacies and the school garden. Literacy Learning in the Middle Years, 21(1), 34-47. 
Pedretti, E., \& Nazir, J. (2014). Tensions and opportunities: A baseline study of teachers' views of environmental education. International Journal of Environmental \& Science

Education, 6(3), 265-283. doi: 10.12973/ijese.2014.215a

Rogoff, B. (2003). The Cultural nature of human development. Oxford, UK: Oxford University Press.

Schneider, J., Kozdras, D., Wolkenhauer, N., \& Arias, L. (2014). Environmental e-books and green goals. Journal of Adolescent \& Adult Literacy, 57(7), 549-564. doi: 10.1002/jaal.286

Shanahan, T. (2006). Relations among oral language, reading and writing development. In C. MacArthur, S. Graham \& J. Fitzgerald (Eds.), Handbook of Writing Research (pp. 171183). London, UK: Guilford Press.

Shoults, C., \& Shoults, L. (2012). Learning STEMs beyond the Classroom. Phi Kappa Phi Forum, 92(2), 25-25.

Skinner, E., Chi, U., \& Learning Gardens Educational Assessment Group. (2012). Intrinsic motivation and engagement as "active ingredients" in garden-based education examining models and measures derived from self-determination theory. Journal of Environmental Education, 43(1), 16-36.

Stevenson, K., Carrier, S., \& Peterson, M. (2014). Evaluating strategies for inclusion of environmental literacy in the elementary school classroom. Electronic Journal of Science Education, 18(8), 1-17.

Stibbe, A. (Ed.). (2009). The handbook of sustainability literacy: Skills for a changing world. Totnes, UK: Green Books.

Street, B. (2001). Introduction. In B. Street (Ed.), Literacy and development: Ethnographic perspectives (pp. 1-17). London, UK: Routledge.

Tangen, D., \& Fielding-Barnsley, R. (2007). Environmental education in a culturally diverse school. Australian Journal of Environmental Education, 23, 23-30.

Tarasuk, V, Mitchell, A, \& Dachner, N. (2013). Household food insecurity in Canada, 2011. Toronto: Research to identify policy options to reduce food insecurity (PROOF). Retrieved from http://proof.utoronto.ca

Taylor, E. (2012). Supporting children's mathematical understanding: Professional development focused on out-of-school practices. Journal of Mathematics Teacher Education, 15(4), 271-291. doi: 10.1007/s10857-011-9187-7

VanDeveer, S. (2011). Consuming environments: Options and choices for 21 st century citizens. Review of Policy Research, 28(5), 517-524.

Walters, L, \& Stacey, J. (2009). Focus on food: Development of the Cooking with Kids experiential nutrition education curriculum. Journal of Nutrition Education and Behavior, 41(5), 371-373.

Walton, C, \& Taylor, J. (2013). Prince Edward Island pilot food costing project report. Charlottetown, PEI: University of Prince Edward Island \& PEI Food Security Network.

Wenger, E. (1998). Communities of practice. Cambridge, UK: Cambridge University Press.

Food and Agriculture Organization of the United Nations. (2015) Hunger Report. Retrived from http://www.fao.org/hunger/glossary/en/

Wilson, S. (2012). Drivers and blockers: Embedding education for sustainability (EfS) in primary teacher education. Australian Journal of Environmental Education, 28(1), 42-56.

Woods, P., \& Hammersley, M. (Eds.). (1977). School experience: Explorations in the sociology of schooling. London, UK: Croom Helm. 
Yagelski, R. (2005). Stasis and change: English education and the crisis of sustainability. English Education, 37(4), 262-271.

\section{Author Biography}

Lyndsay Moffatt is an Assistant Professor in the Faculty of Education at the University of Prince Edward Island. Her research interests include a concern for critical approaches to literacies education and how cultural constructions of literacy and learning challenge and reproduce unequal social relations. Her most recent research focuses on links between ideologies of literacy, education and ecologically un/sustainable ways of living. 